\title{
Inconsistent Coherence in Post-quake Christchurch, New Zealand.
}

\author{
Julian Rennie \\ Departments of Architecture and Landscape Architecture \\ Unitec, Auckland, New Zealand. \\ jrennie@unitec.ac.nz
}

\begin{abstract}
This paper discusses some of the complexities of interactions between people and places in the making and remaking of cities. The paper uses as a case study, Christchurch, New Zealand, which has in the past had the reputation of being the 'Garden City' of New Zealand. Christchurch was hit by a series of large earthquakes occurring between September 2010 to February 2011 (the latter claiming the lives of 185 people). Subsequently many buildings (including houses), were condemned and demolished by the Christchurch City Council (CCC). This resulted in many people closing their businesses, along with families being forced out of their homes and deciding to leave the shattered city. But many people decided the time was ripe for a new type of city to be established; a more humane and considered one. This paper unpacks some of the duelling forces at play shaping the 'rebuild'. On the one hand is the CCC, with its powerbase 'of behind closed door decisions', pushing for a 'framing' of the city that seemingly harks back to its Victorian roots. Working against this is a tide of individuals and small groups that are exploring new directions, via various interventions and new businesses, that speak of how the common person could dwell in this new evolving Urbanity. These events have been fast moving and the cited case studies are researched and explored via close reading of 'formal' central news agency releases and 'informal' social media type responses. The paper is a not only a portrait of what has happened recently in Christchurch but also offers insights into the unique character of its inhabitants, that will continue to be framed by these events. It also suggests ways in which other urban communities could network together and plan possible ways of dealing with natural disasters in the future within their particular milieu.
\end{abstract}

Keywords: Christchurch's 2010-11 earthquakes; Top-down governance; Grass-roots movements; Local Community power 


\section{Background}

When most people think of New Zealand, the rugged mountains and turquoise glacial rivers of the South Island seem to come to mind. New Zealand is small country in the South Pacific, which in 2014 had a population of only 4.5 million people (The World Bank Group, 2015). At that time, New Zealand was also rated the third most prosperous nation to live in (Legatum Institute, 2014). This prosperity index rating supposedly combines economy, entrepreneurship and opportunity, governance, health, safety and security, personal freedom and social capital to generate these ratings.

Christchurch is a provincial city in the South Island; before 2010 it was New Zealand's second largest city, and had a reputation of being the 'Garden City of NZ'. Then, out of the blue Christchurch was hit by a series of large earthquakes occurring from September 2010 to February 2011 (the latter one claiming the lives of 185 people).

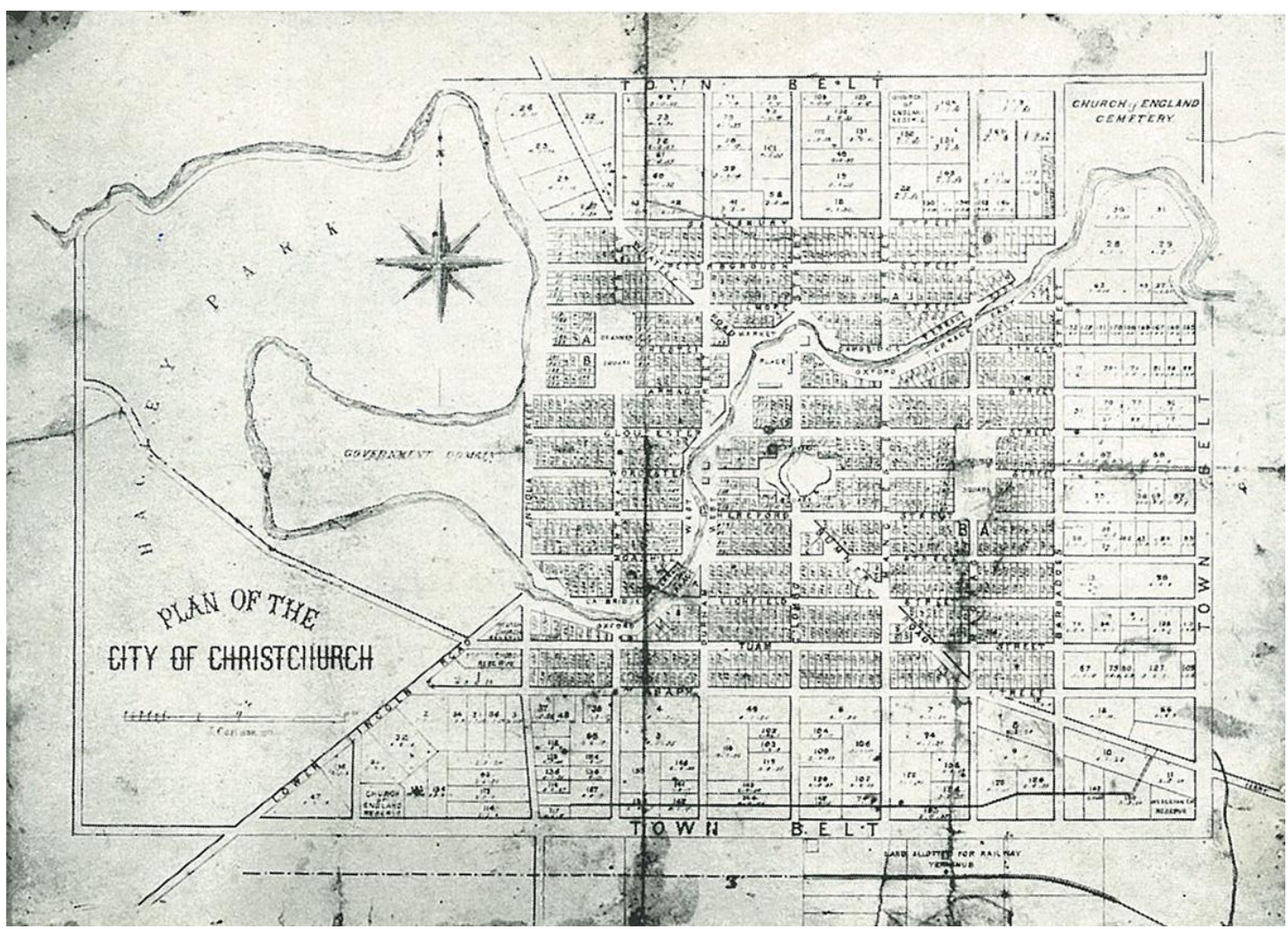

Fig. 1. Plan of early Christchurch drawn by J. Cartman in 1850.

Source: J.P. Morrison (1948, Plate II).

Figure 1 shows the 1850 plan of early Christchurch. Looking at this plan, and without knowing the topography of this proposed new site, the reader might assume that the landscape was flat, and in fact you would be right. However, much of the central city grid was built over an existing swamp, which was part of the Canterbury Plains. These flat plains were deemed more suitable for a city by the city fathers than the original port town of nearby Lyttelton. A set of volcanic hills, known as the Port Hills, separated the natural harbour from the alluvial plains that stretched from the meandering Avon River westwards to the Southern Alps (approximately $90 \mathrm{~km}$ to the West). In all events it took 
some 30 years to establish the drainage system and water supply required to attract settlers to many parts of the new city. The town was for many years "recognized as one of the unhealthiest in New Zealand" (Morrison, 1948;58).

The Southern Alps also discharge their 'winter melt' via large fan gravel rivers, the closest of which is the Waimakariri River. The gravel of such fan type rivers "formed the sub-structure of the plain" (Morrison, 1948;7). It was like "establishing a city on a bed of marbles', something that was not discovered until the quakes of 2010-11. The link between the port and Christchurch city was formalized with construction of the Lyttelton Rail Tunnel in 1867 (and later the construction of the Lyttelton Road Tunnel, completed in 1964). The early rail tunnel allowed agricultural produce (mainly wool, meat, and dairy products) from the Canterbury Plains to be exported direct to colonial 'Mother England' via ship. New Zealand was considered the food basket of the United Kingdom up until the 1960s.

From this 1850 city plan the formal nature of the urban design stemming from its Victorian parentage is immediately clear to the viewer. As Morrison notes: "the disadvantages of Christchurch as a town were in the main the defects of its virtues. The mathematically planned streets of the inner city were of a sameness that confused the newcomer" (Morrison, 1948;158). Only the slow moving Avon River snaking from West to East (from left to right in the above drawing), adds some relief to the grid of the city blocks and this river soon added to the character of the city which developed in the mould of a small Cambridge, England (with its River Cam).

\section{Introduction}

Historian Michael King intones about New Zealand attitudes, values and habits which include: "a willingness to have a go at any kind of job opportunity that presented itself;... a concern for the underdog; compassion for those in need or in trouble; an unwillingness to be bullied, or to be intimidated by class or status" (King, 2000). That said, we Kiwis live in a democracy. We vote freely for our regional members of Parliament that go towards forming the Government of the day; and we also vote in our Council members to serve us locally. Yet, within the New Zealand triennial local body voting system, for years: 2004, 2007, and 2013, the Christchurch City October elections attracted just $38.77 \%$ to $42.78 \%$ of Cantabrians to come out and vote for their council representatives. A spike did occur in the October 2010 election (just one month after the initial earthquake), where $52.15 \%$ of the residents voted (ElectionNZ.com. 2013). This paper suggests that 'leadership was sought at a time of tragedy', and the subsequent 2013 slump in voting numbers seems to reflect a return to a rather cynical 'same as, same as' regimen. New Zealand has, like other democracies, overarching bodies of governance. Behind these elected bodies are the bureaucrats that carry on the running of the country, towns, and cities in a relatively smooth manner. However extraordinary events can focus attention upon the performance of large scale bureaucratic departments, and today with widespread and easily accessible social media the common person can make their opinion widely and strongly heard. Democracy also brings individual freedom within each person's life allowing them 
eligibility to attend school and find work, to make a living to support themselves and their families.

The Christchurch earthquake of 22 February 2011, a 6.3 Richter scale quake (which claimed the lives of 185 people), resulted in many office buildings, apartments in the Central Business District (CBD), and houses out in the suburbs being 'red stickered', and so basically condemned by the Christchurch City Council, (CCC). As a result many businesses and families were forced out of their buildings and homes; and subsequently some such land / property owners decided to leave the region. However many residents decided to remain, seeing this as a possible 'new start' and have set up new and sometimes provocative businesses, often borne out of necessity and practicality, yet at the same time rethinking how they might now like to live within this new 'timespace'.

\section{Methodology}

This paper is written just five years after the traumatic Canterbury earthquakes, and has a phenomenological approach as its methodology. The study seeks out meanings from people's perceptions, perspectives and experiences that have resulted from these particular events via 'close reading' of various blogs, newspaper articles, and websites. These experiential texts, although often written with great lucidity are also emotive due to the unexpectedness and scale of the calamity. However this same clarity speaks of the complexities around the interaction between people and place. The resultant distilled meanings are set against a background of literature of similar situations. Although this paper is a 'snapshot in time', there are some 'signposts' that point the way to how we might deal better with similar natural disasters in the future.

\section{Discussion centred around some of the initiatives by the 'common people'}

\section{Timebanking}

"Project Lyttelton set up New Zealand's first Time Bank in 2005" (Project Lyttelton Inc., 2011). Lyttelton is now an outlying suburb to the south-west of Christchurch city, but remains the city's port. In the immediate aftermath of the February 2011 quakes the 'sense of community' and people's willingness to reach out and help each other and care can be highlighted by Lyttelton's efforts via 'Time Banking'. Rakowski claims that one of the definitions of 'urban informality' that most scholars agree on is: "the [associated] activities...share at least two characteristics. They tend to be small scale and their workers usually are not protected by [labour] law" (Rakowski, 1994, p.274). Time Banking "originated in the USA in the 1980s from the work of Edgar S. Cahn. Since then it has spread worldwide... No matter what type of work is done, one hour always equals one time credit. $1=1$. Every person is equally valued" (Project Lyttelton Inc., 2011). Because the Lyttelton Time Bank (LTB) had been set up prior to the quakes they already had an online data base of its hundreds of members and their skill sets on offer to trade. In the time leading up to the quakes "some 30,000 trades [were transacted...from which] evolved a stronger social network...built through these trades" (Ozanne \& Ozanne, 2013, p.4). 
During the actual crisis of Christchurch earthquakes of 2010-11, the LTB was able to mobilize its local resources thereby freeing up trained emergency workers to assist on projects that needed greater skill, for example:

"The volunteer fire brigade, ambulance and Health Centre asked the [LTB] to start coordinating volunteers...Teams of people helped take down dangerous chimneys, called up older people in the community to check if all was OK, and provided a drop in centre for people to simply touch base with other humans," (Project Lyttelton Inc., 2011).

This hub of communal knowledge and skill base was tested in real-time 'trial by fire' type experiences and can now help prepare future civil disaster organizations, as a demonstration that "bottom-up, grassroots organising often provides a more effective and nuanced response than is provided by top-down bureaucratic processes that offer a one size fits all approach" (Ozanne \& Ozanne, 2013, p.5). This outcome has similarly been noted in the aftermath of Hurricane Katrina: "preparedness [is one of the key essentials]...of crisis management systems" (Moynihan, 2009, p.7).

\section{Urban waste recycling}
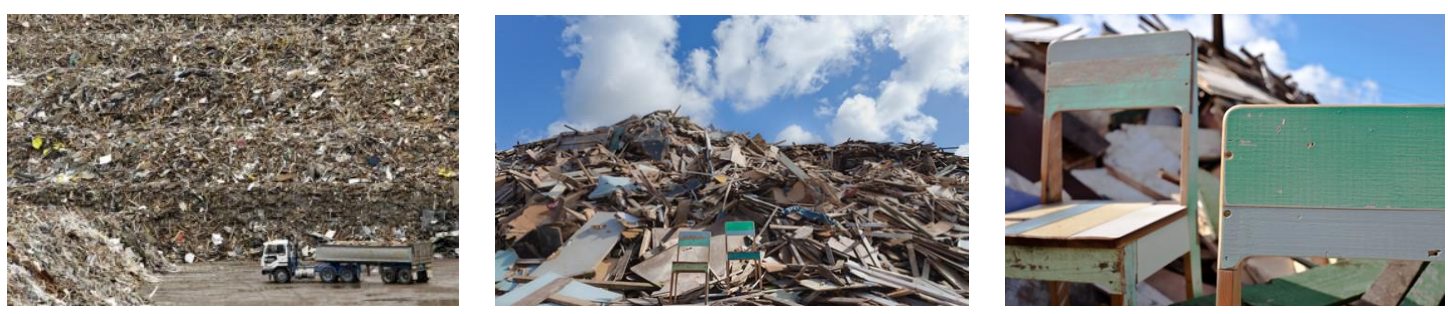

Fig. 2. Burwood Resource Recovery Park and Rekindle's chairs amidst the mountain of timber landfill. Sources: David Hallett and Rekindle's website.

One response to the hurried demolition of many damaged buildings within Christchurch, (with the resulting 'spoil' being trucked off to outlying landfill sites), was Rekindle, a company set up by Juliet Arnott in 2012. Her company was specifically set up to re-use the native timbers that made up a prominent part of Christchurch (and typically New Zealand's 'timber balloon frame, timber clad homes') in Rekindle's range of manufactured timber furniture products. Rather than such demolition timbers ending up crushed as landfill, Rekindle engaged with 'salvage' and 'recycling' as its modus operandi, with obvious environmental and economic benefits to the community. Such native timbers are now no longer available on the market are therefore irreplaceable. Rekindle goes further to claim that there is significant cultural benefit: "each home also contains a story of social history - time encapsulated in layers of paint and wallpaper...memories big and small" (Arnott, 2012). The retention of such patinations and colours of the original house timbers that are now exposed and given a new life within Rekindle's chairs and tables is just one example of how it is possible to add new nuances of meaning and continuance related to these specific 'dwellers and their place'. 


\title{
Temporary use of vacant urban sites
}

As a result of the wholesale building demolitions across the city and especially within the CBD, many properties ended up as empty sites. Life in Vacant Spaces (LIVS) is an independent Trust set up in June 2012. It acts as an organization working with other community volunteer groups such as: Gap Filler, FESTA, and Greening the Rubble. LIVS strives to manage privately owned property for landowners that have had their buildings demolished and seeks out short and medium-term uses for the countless vacant sites within the central city zone. "[Their] mission is to cut through red tape and unlock permissions, making vacant space available to creative Christchurch and enabling hundreds of temporary activations" (LIVS, 2012). One of the groups under this LIVS's umbrella is Agropolis Urban Farm, which is similar to the 'sustainable urban agriculture' movements of the 1990s such as the Organopónicos of Havana, Cuba (set up to grow food in urban Havana due to the trade embargos put in place by the American Government).
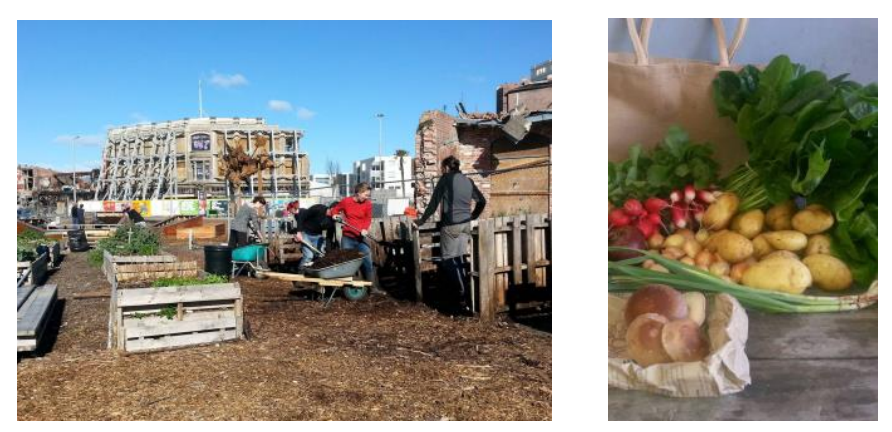

Fig. 3. Images of Agropolis Urban Farm

Source: Agropolis Facebook page

\begin{abstract}
"This is a scalable transitional urban farm within Christchurch's inner city. It involves composting organic waste from inner city hospitality businesses as well as the ground preparation, sowing and planting, harvesting, cooking and distribution of the produce... [They intend to expand the enterprise] into an urban food hub including creating a mobile kitchen that can be used for 'garden to plate' experiences and educational opportunities with the community, schools and beyond." (LIVS, 2012)
\end{abstract}

Is this a twist on the city's previous reputation, a 'new Garden City' of New Zealand?" Can local communities make temporary yet legal use of vacant urban ground that can enrich and educate urban children about where their foodstuffs come from?

\section{Temporal architectural interventions}

FESTA (Festival of Transitional Architecture) is another new volunteer group, which sprang up following the disaster to investigate this new temporal realm within Christchurch (initially held annually over the October 'Labour Weekend'). This group of local people claim that: "Christchurch has an unparalleled opportunity to be a global 
epicentre for creative urban renewal through transitional and experimental architecture, art and performance" (FESTA, 2012). FESTA go on to say:

"Large and small transitional projects have already provided a way of creatively and immediately reoccupying and regenerating the central city. They give us a chance to experiment, meet pressing needs and they inform our long-term decisions. FESTA desires to harness the community's craving to be involved in creating their city. This festival will be an on-going and unique event that learns from and informs the exciting transitional city." (FESTA, 2012)
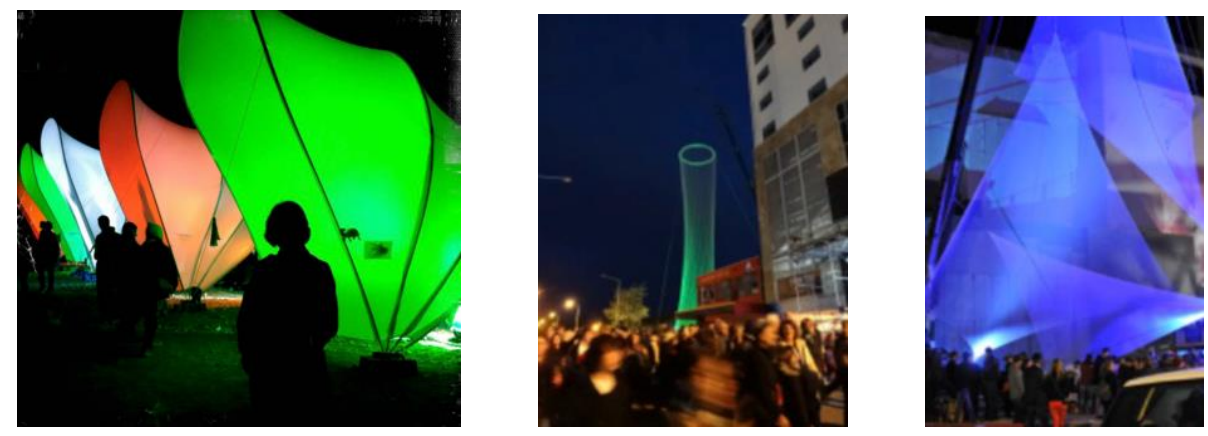

Fig. 4. Images of LuxCity 2012 for FESTA

Sources: Unitec student groups: Silhouette Carnival, Altitude, and Archrobatics respectively.

The author was just one of the architectural tutors that helped six groups of Architectural students from Unitec, Auckland to realize their built projects on how 'one might create a city from light for one night' (the event was held on the evening of 27 October 2012). The six Unitec installations were part of the total 16 designed and fabricated by over 350 architecture and design students from across New Zealand.

The built installations used light and light-weight materials (such as rope, grapevine mesh, modern nylon stretch knit fabrics, uPVC conduit and so forth) to create various and varied temporary spaces for one evening. The spaces catered for activities such as bars, cafes, live music and performance venues. This form of 'real life' learning encountered by the second year B.Arch. students was contrary to other modes of tertiary learning, where students often design projects in 'silo type' isolation, away from real sites, real clients, distant from money related issues and seldom involving 1:1 scale fabrication. For this FESTA event the students not only did the traditional production of design drawings, models, through various iterations; they also had to present to 'real clients,' (the owners of the above bars and cafes). The students had to adapt and modify their original designs to accommodate their clients. They also had to produce websites and presentations suitable for pitching to potential commercial sponsors and /or donators of product to help with the realization of their projects. In addition, the students had to come up with ways of generating funding (cake sales, raffles, art auctions and so forth) to comply with the Brief that had stipulated a 'zero budget'. Although it seemed daunting to most students to approach a business and ask for a 'hand-out' or borrow some equipment, almost all of the students reported back 
that commercial CEOs wanted to help Christchurch, wanted to do something, but did not know how to do so in a meaningful way.

The 2012 event was FESTA's first such 'happening,' with an expectation of 2000 people attending the 'one off' night time event. On the evening, in actual fact over 20,000 people attended (FESTA claim 30,000). It turned out that this was the first time that many Cantabrians had returned to the CBD since that disastrous 22 February 2011 day (some 20 months earlier). It was an emotional outpouring of awe and warmth for a few hours by the Christchurch city's inhabitants, many of who were still living in broken homes and still without functioning toilets. In the words of a fellow tutor's Christchurch-resident sister, as relayed to the author: "A time to forget, even if it was for just a few hours" (Kelderman, 2012). This paper asks: is this a form of forgetting not only for the individual but for the city? By engaging with something new, rising phoenix like from a particular tainted site, for a very short period of time (4 hours), is this a way of creating some small joy for a collective audience? Perhaps Paul Ricoeur (2004), with his deep meditations about forgetting as a way of humane negotiation between memory and history, might agree.

\section{Discussion centred around some of the initiatives by various 'Authorities'}

In the aftermath of these earthquakes various 'top down' bureaucratic organizations were also working on re-build type projects within the city of Christchurch, in contrast to 'bottom up' type community driven ones as exampled above. These projects have been driven from the Government level (e.g. CERA: Canterbury Earthquake Recovery Authority) as well as from the local Christchurch City Council (CCC). Much research has been done into such unilateral responses: often such "top-down measures as a standard response are especially focused on...institutional uncertainty...to reduce or eliminate freedom of action for other participants" (Koppenjan and Klijn, 2004, p.8). Although the New Zealand Government and the CCC may not have been thoroughly primed to deal with such wide scale devastation, the seeming lack of consideration for the affected local communities has left many residents in a state of frustration and disbelief.

\section{Christ Church Cathedral / Cardboard Cathedral saga}

One such example is whether or not to rebuild the city's Anglican Cathedral 'ChristChurch Cathedral', which lost its stone and copper spire and much of the stone nave during the quakes. Seemingly, the Anglican Church itself doesn't want to pay for its own Cathedral's repair; it has 'moved on' and commissioned the so-called 'Cardboard Cathedral' (designed by Japanese Architect Shigeru Ban). This 'transitional cathedral' has been built (it opened in August 2013) on the site of another church, the former 'St John's on Latimer Square'. The original St John's church was demolished after being badly damaged in the Canterbury earthquakes. The new "cathedral had a budget of NZ\$5.3milion, and the final costs have been reported to be 5.9 million New Zealand dollars, [which is, approximately LKR 522million]" (Dennis, 2013). Some NZ\$4.0 million [LKR 355milion] of construction costs were largely paid for by the insurance monies from the damaged, (but currently still standing) 
'ChristChurch Cathedral', an act a High Court Judge has "deemed may be illegal" (Mead, 2012). In addition, controversy raged about a maintenance fund (NZ\$240,000.00 per year, [LKR 21million]) that the Anglican diocese used to get from the Christchurch City Council (this is city rate payers' money), which was applied for again in 2012 to help towards the budget shortfall of NZ\$1.9 million [LKR 168million]. The city councillors turned the request down (King and O'Callaghan, 2013).
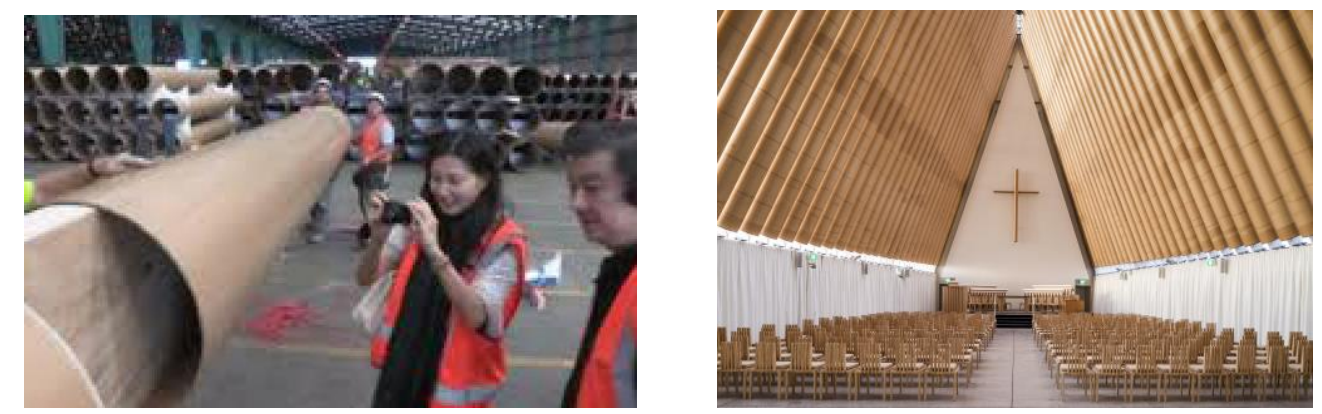

Fig. 5. Cardboard Cathedral: Images of the cardboard tubes during construction and completed interior

Sources: seismic.org.nz and time.com respectively

Other political and symbolic decisions made by CERA and the Anglican Church client revolved around the use of cardboard tubes as a 'structure' for a 'temporary building'. There are a few inconsistences that confirm that such decisions have been in a large part 'a public relations exercise'. For instance, under the New Zealand Building Code for such a building to get a Building Consent, the design would have to be able to stand up for 50 years. Is that really temporary? And, the 'cardboard tubes' it turns out are not structural at all, as was explained when some of the tubes got wet and started to wrinkle:

"Naylor Love Construction director Scott Watson said...[t]he cardboard columns were cosmetic only, with the building load carried by timber beams concealed inside the tubes." (Gates, 2013)

This paper contends that the New Zealand Building Code says nothing about the use of 'cardboard as a structure', and that our New Zealand structural engineers probably would not be able to produce a 'Specific Design' for such 'cardboard columns' that would satisfy our Building Code. Thus it probably was always going to a timber structure (that would comply with the Code), and the cardboard tubes merely camouflage for the timber structure.

The costs as outlined above, do seem an awful lot of money to build a monument to an ever-diminishing number of believers. As at least one local inhabitant notes, "attendances at the old cathedral before the earthquakes ruined it were as low as 70 for a Sunday service, and of those about one third were [visiting tourists]" (Henry, 2014). This author agrees with many that the 'ChristChurch Cathedral' was an iconic symbol for the locals via its 'spire rising up off the Canterbury plains', but this paper also 
questions: are such monuments really required for our society in this social media driven society? Recent visits by the author to this 'cardboard Cathedral' reveal that the project seems to be largely a money gathering exercise with buckets for donations displayed prominently inside the entry; is that how places of worship normally conduct themselves?

\section{Urban infrastructure issues}

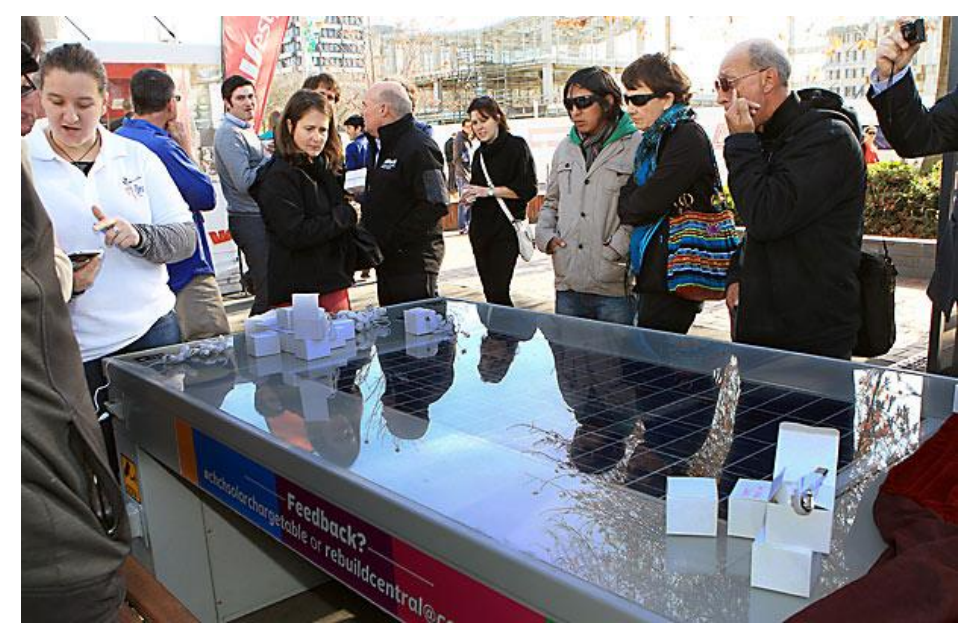

Fig. 6. New Zealand's first public solar-charge table Source: The Christchurch Press

In an attempt to show that the Christchurch City Council was regaining some semblance of control and that it 'had its finger on the pulse', it installed a 'solar table' (19 May 2014). The Council claimed to have "launched the country's first free public solar-charge table, allowing users to plug in their smartphones or tablets to charge while hanging out in the food-court at [the] Re:Start Mall" (Squires, 2014). The 'for and against' online feedback to such an initiative is currently approximately equal. But the intensity of the naysayer's responses outweighs the votes of support. One such example, (by a respondent named "Kuzak") is:

"What a waste of rate payers money. The CCC yet again wastes money on PR rather than fixing things that are broken. So you have to stand and wait with your phone while it gets charge, what a waste of time. Car phone charger, desk charger and back up batteries are cheap - it should be users responsibility to charge their phone not the ratepayer... Maybe the [thousands of dollars] spent could have been spent on things that impact people (and their cars) like the holes in the roads on the East side of town. Nice how the west side get new footpaths and roads touched up again, while the east still waits." (Squires, 2014)

Who decides to spend the rate payers' money in these projects? When the 'man-in-the street' type projects may not find favour with the Council and don't get 
financial backing, in fact such non-action often seems draw the communities even closer together and Kiwis work out ways of how to 'get on and just do it'. This concurs with Koppenjan and Klijn's finding that "when [top-down] attempts are made to exclude actors from participation in the problem solving process... resistance is created since the interests of these actors are ignored" $(2004 ; 8)$.

As further evidence of the CCC not performing for its citizens, even as recently as September 2014, there remained many people still without working toilets years after the quakes. For example in the suburb of Waltham "a cottage has not had a working sewer since the February 2011 earthquake. [The occupant] used a chemical toilet for more than two years but when the Christchurch City Council removed kerbside dumping stations [Port-a-Loos] last year, [the occupant] resorted to using a bucket" (Stylianou, 2014).

\section{Building Consent Accreditation Issues}

Christchurch City Council has had much criticism from within the local community. To make things worse in July 2013 the CCC was stripped of its accreditation to issue Building Consents by International Accreditation New Zealand (IANZ) (Cairns, \& Young, 2013). These consents are building permits that allow people permission to carry out intended building works. So, just 17 months after the fatal earthquake, and with the city's residents reeling from insurance company non-pay outs and the CCC continuing to charge rates on properties that had been deemed not inhabitable, the Council was relieved of one of its key duties. People wanting to get on with their lives by carrying out building works to fix up their damaged buildings so business's could restart or houses could be made habitable again found themselves in limbo. As a result building consents were then farmed out to other city councils around the country, with CCC merely acting as a 'postman'. But to be fair, no one saw these tragic events coming; there was a joke doing the rounds that the earthquake fault line under the River Avon had been forgotten about for 25,000 years! Largely the people who worked for the council were caught off guard and found wanting; few had experienced firsthand such an event. Little wonder then that Christchurch locals felt further let down by its elected local body. It was not until December 2014 that its building consent issuing status was reinstated (Mead, 2014). 


\section{Reframing the city}

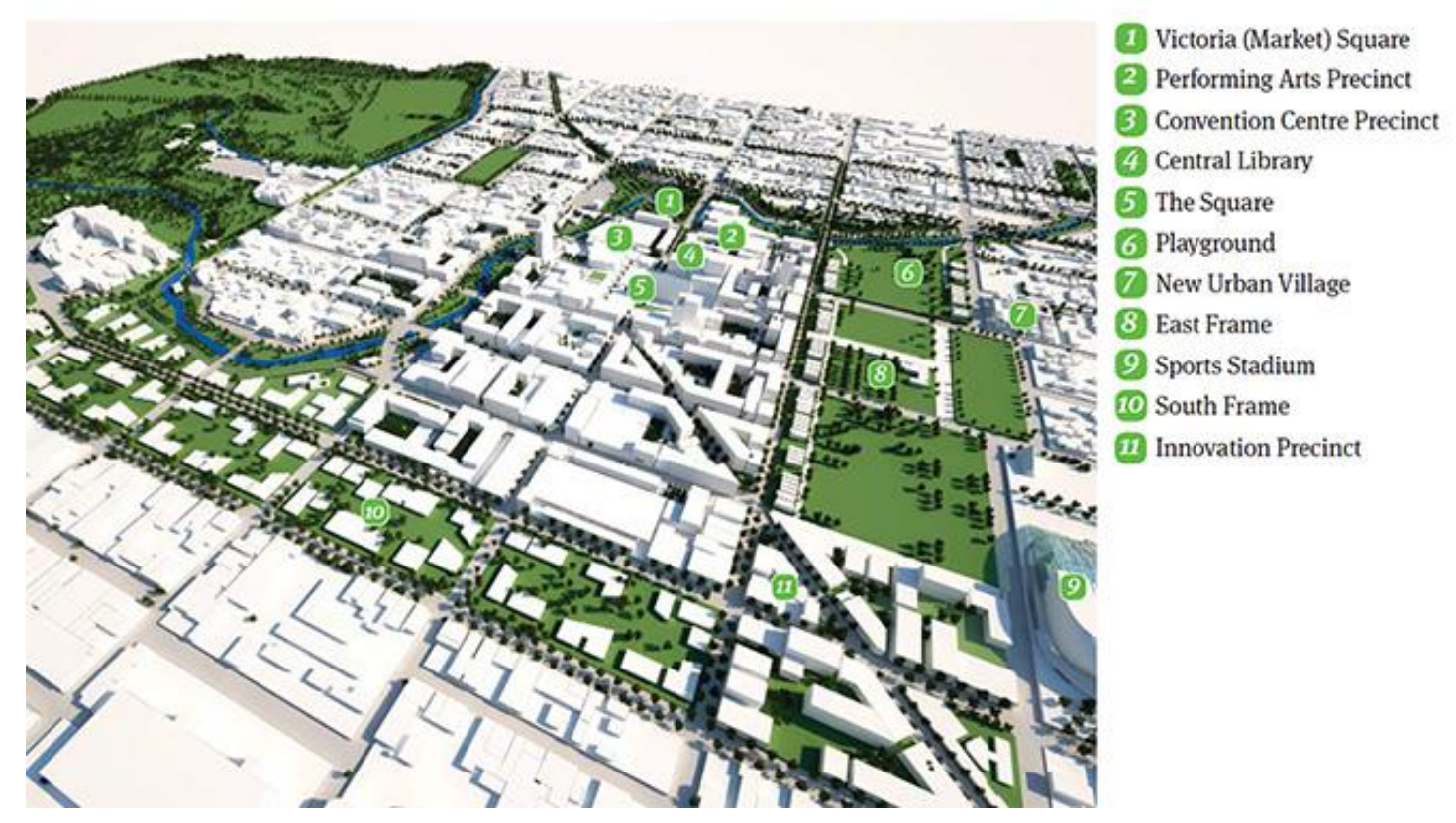

Fig. 7. Proposed East and South Frame to Christchurch, showing key project locations, 2012

Source: Image is part of the information pack of 'Breathe, the architectural competition for a new urban village,' held in 2012 (CCC)

Figure 7 shows an aerial view of the Christchurch City Council's Christchurch Earthquake Recovery Authority's, Te Rūnanga o NGĀI TAHU's, and the New Zealand Government's proposed strategy of 'framing' the earthquake shattered CBD with the 'East and South Frames'. In fact these same framing devices can be seen in Figure 1 above, where the original Christchurch city grid is bounded by the 'east and south town belts'. So it would seem in fact that the current 'powers that be' (predominantly the government and CERA) are intending some sort of 'back to the future' type strategy, including the retention of the CBD on its current site, yet the gravel of the fan type rivers that form the sub-structure of the CBD are still there below. Will this 'grand formal gesture' of 'coherently framing' the CBD make everything right and worthwhile? In addition, these 'frames' are currently privately owned valuable inner city land that will be somehow compulsorily purchased and merely grassed over!

And still the saga continues to unravel. CERA is currently moving ahead with various 'anchor projects' within this grand frame scheme, giving little or no detail to the public, despite the fact it involves taxpayer's money. One such is the new Convention Centre, which as recently as 29 July 2015 made the national headlines with the news that "NZ\$77 million [approximately LKR 681million], has already been spent or is about to be spent for land [and consultant fees]...all this on a project that still has no finalised budget or start date for construction" (Young, 2015). Whether this and other just 'grand formal gestures' will come to fruition on the old CBD 'bed of marbles', only time will tell. 
Will the decentralising way in which we now live with social media and the internet actually require us to live in a 'framed coherent' city like our Victorian founders? Or can we engage in a multi-layered and vibrant urbanity which fosters different activities that engage in (rather than merely paying lip service to) local community power, recycling, sustainability, together with a lightness of touch upon the planet that make for an inconsistent coherence by providing more variety, more choices for people and thus a more humane place in which to dwell?

\section{Conclusions}

In line with most New Zealanders' suspicion of large organizations (they tolerate them at best) and Kiwis' traditional 'championing of the underdog', this paper would like to suggest that the 'top down' actions of the Christchurch City Council and CERA are at seemingly at odds with the intimate and community specific activities that have sprung up around this city since the tragedy. Although such interventions are small and often temporary, they speak volumes about how they their new city 'could be'. And yet the 'powers that be' continue to not listen to the communities that voted them in in the first place. The coherence of the city is inconsistent at best, each side adhering to themselves, with perhaps the only distractions that bind the city for a few moments such as those when people come out and support, with long held pride the local Canterbury Rugby side, or as shown above the unique FESTA events.

Whether the duel is equal or not, the top-down driven powers seem to be ploughing on ahead with often grandiose schemes amid political shenanigans. Only time (and no doubt money) will tell how such schemes will evolve or devolve, but meanwhile the average person carries on 'living like an ant'. But for now it seems (and the author is reluctant to say it), 'history repeats.' The city of Christchurch from the time of inception took 32 years to drain the swamps in a sanitary way, upon which large areas of the city were then built:

"Municipal liberty for a while was given precedence before considerations of health. While the City Council disputed with this County or Borough Council and that Road or Town Board as to who was in fact responsible for an offensive drain, those in the neighbourhood of the drain protested and petitioned the authorities in vain. Throughout the records of City Council and Board of Health meetings there are minutes of resident's complaints, warnings to offending citizens, and Sanitary Committee reports recommending this and that measure to improve the state of health in the district" (Morrison, 1948;58).

The current residents of the suburb of Bexley (many of whom are still without functioning toilets in their houses), could 'fast forward' 135 years and those same comments still apply between themselves and the local and national authorities. 
And, as Bailey Peryman says:

"So much has been committed on our behalf, without our permission and without any kind of consensus, stuff that's going to have a huge impact on the shape of our city. [He also adds] That the problems we're facing have their roots before the earthquakes...I think the whole recovery thing is a misnomer. We need to throw the idea of recovery out the door and go back to the transitioning to something better." (Sherow, 2014)

This paper has presented a series of snapshots in and around the Canterbury region, the case studies being taken from within the period of September 2010 to September 2015. The rebuilding of the city is set to take (in some people's opinion) a further 25 years. The paper provides some insights into the complexities of how cities, people, and places are intertwined, and the friction and frisson of these interactions, suggesting that these tensions will continue to inform the reformation of this shattered city. This 'portrait in time' shows community bonding and networking techniques for mutual help, recycling urban waste ideas, outlines outcomes of temporary occupation of land owned by others, and highlights the local citizens' questioning of the logic and worth of Governance decisions, both in the short and long term, which affect current and future city dwellers of Christchurch, New Zealand. The door is open for other researchers to monitor (in perhaps 5-year cycles) the Christchurch rebuild and reflect further on the resulting outcomes.

\section{References}

ARNOTT, J. 2012. Rekindle [Online]. Christchurch, New Zealand. Available: http://www.rekindle.org.nz/pages/community [Accessed 18 July 2015].

CAIRNS, L. \& YOUNG, R. 2013. Council set to lose consenting power [Online]. Christchurch: The Press. Available: http://www.stuff.co.nz/the-press/news/8862238/Council-set-to-lose-consenting-power [Accessed 18 July 2015].

DENNIS, A. 2013. Budget shortfall for Christchurch's tubular cardboard cathedral [Online]. Sydney: The Sydney Morning Herald. Available: http://www.traveller.com.au/budget-shortfall-for-christchurchs-tubular-cardboard-cathedral-2e3o5 [Accessed 27 September 2014].

ELECTIONNZ.COM 2013. Christchurch City Council $\square 2013$ Triennial Elections Election Return: as at 25 October 8:08am. http://www.electionz.com/elections/lgereturns/ELT60CH13 returns.htm.

FESTA. 2012. Festival of Transitional Architecture [Online]. Available: http://festa.org.nz [Accessed 2 September 2014].

GATES, C. 2013. Rain leaves cathedral tubes soggy [Online]. Christchurch, New Zealand: The Press. Available: http://www.stuff.co.nz/national/8937828/Rain-leaves-cathedral-tubes-soggy [Accessed 27 September 2014].

GROUP, T. W. B. 2015. Data: Population Total [Online]. Washington DC. Available: http://data.worldbank.org/indicator/SP.POP.TOTL [Accessed 19 July 2015].

HENRY, P. 2014. "A waste of money?" Review of Cardboard Cathedral [Online]. Newton, Massachusetts, USA: Trip Advisor. Available: http://www.tripadvisor.co.nz/ShowUserReviews-g255118-d4735869-r201623354-Cardboard_Cathedra 1-Christchurch_Canterbury_Region_South_Island.html\#REVIEWS [Accessed 27 September 2014].

KELDERMAN, M. 2012. RE: What is the use of having an event like LuxCity 2012 in earthquake ravaged Christchurch CBD? Type to RENNIE, J. J.

KING, M. 2000. Allegiance to One's Origins: The Consequences of Belief. Sea of Faith Network (NZ) Conference: 
"Beyond Belief-Putting Faith Into Practice". Havelock North.

KOPPENJAN, J. \& KLIJN, E.H. 2004. Managing Uncertainties in Networks:

A Network Approach to Problem Solving and Decision Making, New York, New York, Routledge.

LEGATUM INSTITUTE. 2013. The Legatum Prosperity Index Report, 2013. London, UK.

KING, C. \& O'CALLAGHAN, J. 2013. Cardboard project frontman loses job [Online]. Christchurch, New Zealand The Press. Available:

http://www.stuff.co.nz/the-press/news/christchurch-earthquake-2011/8917943/Cardboard-project-front man-loses-job [Accessed 09 October 2014].

LIVS. 2012. Life in Vacant Spaces [Online]. Christchurch. Available: http://livs.org.nz/home/ [Accessed 02 October 2014].

MEAD, T. 2012. Anglican Church starts fundraiser for Christchurch Cardboard Cathedral [Online]. Christchurch, New Zealand 3 News: MediaWorks TV. Available:

http://www.3news.co.nz/nznews/anglican-church-starts-fundraiser-for-christchurch-cardboard-cathedra 1-2012112910 [Accessed 09 October 2014].

MEAD, T. 2014. Christchurch City Council regains building consent accreditation [Online]. Christchurch. Available:

http://www.3news.co.nz/nznews/christchurch-city-council-regains-building-consent-accreditation-2014 121811\#axzz3hgvGFSIU [Accessed 09 October 2014].

MORRISON, J. P. 1948. The Evolution of a City, Christchurch, New Zealand, Whitcombe and Tombs Ltd.

MOYNIHAN, D. P. 2009. The Response to Hurricane Katrina. In: I. R. G. C (ed.) IRGC report: Risk Governance Deficits: An analysis and illustration of the most common deficits in risk governance. Geneva, Switzerland.

OZANNE, L. K. \& OZANNE, J. L. 2013. Developing Local Partners in Emergency Planning and Management: Lyttelton Time Bank as a Builder and Mobiliser of Resources during the Canterbury Earthquakes.

PROJECT LYTTELTON INC., 2011. The Lyttelton Time Bank played a vital part in the local response to the recent New Zealand quakes [Online]. Lyttelton, New Zealand Project Lyttelton Inc. Available: http://www.lyttelton.net.nz/earthquake/206-the-lyttelton-time-bank-played-a-vital-part-in-the-local-res ponse-to-the-recent-new-zealand-quakes [Accessed 20 September 2014].

RAKOWSKI, C. A. (ed.) 1994. Contrapunto: The Informal Sector Debate in Latin America, Albany, USA: State University of New York Press.

RICOEUR, P. 2004. Memory, History, Forgetting, Chicago University of Chicago Press.

SHEROW, B. 2014. Creative Thinkers of Christchurch: Bailey Peryman [Online]. The Pantograph Punch. Available: http://pantograph-punch.com/post/bailey-peryman [Accessed 05 August 2015].

SQUIRES, S. 2014. Re:Start installs first solar-cell charger. Available: http://www.stuff.co.nz/the-press/news/city-centre/10061571/Re-Start-installs-first-solar-cell-charger [Accessed 22 September 2014].

STYLIANOU, G. 2014. Sewerage a pipe dream for man still using a bucket [Online]. Christchurch: The Press. Available: http://www.stuff.co.nz/the-press/news/christchurch-earthquake-2011/10471554/Sewerage-a-pipe-drea m-for-man-still-using-a-bucket [Accessed 09 August 2015].

YOUNG, C. 2015. Still few clues on convention centre cost [Online]. Christchurch: Radio New Zealand News Available: http://www.radionz.co.nz/news/regional/279938/still-few-clues-on-convention-centre-cost [Accessed 09 August 2015]. 